\title{
RECOGNITION AND EXECUTION OF FOREIGN CRIMINAL DECISIONS
}

\author{
Holta Seferi \\ Ministry of Education, Sports and Youth \\ Tirana, Albania \\ E-mail: holta.seferi@arsimi.gov.al
}

\begin{abstract}
One of the forms of judicial cooperation with foreign authorities is the recognition and execution of foreign criminal decisions, which, more than any other form, is based on solidarity between states, strengthening and facilitating international relations, increasing trust to each other's authorities.

Within the Council of Europe, there are two important Conventions in this field, the European Convention on the International Validity of Criminal Proceedings, The Hague, 1970 and the Council of Europe Convention on the Transfer of Sentenced Persons, 1983.

These conventions are also the main acts for the regulation of international relations in this field, which have also served as the main basis on which our legislator has relied in the formulation of the provisions of Chapter III, Title X, the Code of Criminal Procedure, Section I "Execution of foreign criminal decisions", as well as the approval of law no. 10193, date. 03.12.2009 "On jurisdictional relations with foreign authorities in criminal matters", as an attempt to approximate legislation with the acquis communautaire.

This article will address the provision of national and international legislation in the field of recognition and enforcement of foreign criminal decisions and its implementation in practice.

The methodology used in this article is the legal analysis of international cooperation in this field, focusing on national legislation and its application in case law, regarding the execution of foreign criminal decisions in Albania and the execution abroad of Albanian criminal decisions.
\end{abstract}

Keywords: Convention, execution, criminal decision, court, prosecutor, cooperation.

\section{Introduction}

Today, more than ever, the need for peace and security has become a top priority. New forms of crime and its global consequences have led states, in response, to intensify cooperation between them and in addition to existing forms of cooperation, to find new instruments and mechanisms to increase the effectiveness of their relations in the international criminal arena.

One of the forms of judicial cooperation with foreign authorities is the recognition and execution of foreign criminal decisions. This form of judicial co-operation has had a significant impact on strengthening and facilitating international relations between states, making co-operation between them more effective on the one hand and increasing trust in each other's authorities on the other. Recognition and execution of foreign criminal decisions is a form of cooperation, which more than all other forms, is based on solidarity between states.

As for the application of other forms of cooperation, in the application of this form states are free to conclude bilateral or multilateral agreements at the international level. In the framework of the Council of Europe, there are two important Conventions in this field, which are: 
- European Convention "On the international validity of criminal trials", The Hague, 28.05.1970, which was ratified in Albania by law no. 9068, dated 15.05.2003;

- Council of Europe Convention "On the Transfer of Sentenced Persons", dated 21.03.1983, ratified in Albania by law no. 8499, dated 10.06.1999.

These conventions are also the main acts for the regulation of international relations in this field, which have also served as the main basis on which our legislator has relied in the formulation of the provisions of Chapter III, Title X, the Code of Criminal Procedure, Section I "Execution of foreign criminal decisions".

Unlike extradition, which is limited to the nature of the crime and its punishment, these criteria are not essential conditions for the implementation of this form of cooperation. The application of this form of co-operation is closely linked to the simultaneous expansion and narrowing of the jurisdiction of the states participating in the co-operation. Thus, the State seeking recognition and enforcement of a sentence or security measure in another State extends the jurisdiction of its judicial authority, while the executing State acquires jurisdiction over the enforcement of a decision not taken by the authorities of the he thus loses jurisdiction over the matter when he executes the decision of another state.

\section{Execution of foreign criminal decisions in Albania.}

The judicial authorities of the Albanian state become competent to implement a criminal decision given by a foreign court when two conditions are met: the convicted person is in Albania and has a request for the execution of the decision by the competent authority of the foreign state.

The application of cooperation in this field is related to three important elements:

a) The decision must have been given in relation to a criminal case;

b) The sentence must be the result of a criminal proceeding (the fine or seizure must have been imposed by the court as a criminal sentence and not as a civil obligation);

c) The decision must have become final according to the law of the state that requires its recognition and execution in Albania.

Another case of recognition of a foreign court decision is the one under the Strasbourg Convention "On the Transfer of Sentenced Persons" (21.03.1983), according to which a person who is serving a prison sentence in a state, a citizen of who is not, may request to serve the remainder of the sentence in his country of origin.

The application of this form of cooperation aims at two main objectives:

1. preventing the convicted person from escaping punishment;

2. facilitating the process of its rehabilitation.

It is clear that serving the sentence in the country of origin by the convicted person is more favorable for his faster rehabilitation, as the sentence in this case is served in his family and social environment.

By state of origin is meant not only the state of which the person is a citizen, but also the state where he resides and has spent most of his life, ie the state with which the person has the strongest affective connection. Consequently, the subject of these relations will be the Albanian citizen who has committed a criminal offense outside the Albanian territory, ie in the territory of the requesting state, or a foreign citizen who is resident in Albania and has committed a criminal offense punishable under the law of the requesting state.

These two cases are expressly provided in Article 53 of Law no. 10193, date. 03.12.2009 "On jurisdictional relations with foreign authorities in criminal matters", as amended.

The decision of a foreign court on imprisonment can be recognized: 
a) at the request of the sentencing state, when the convicted person is an Albanian citizen and has a residence or domicile in Albania;

b) at the request of an Albanian citizen serving a sentence in the sentencing state, for transfer and continuation of serving the sentence in Albania ${ }^{1}$.

Regarding the procedure followed, the Code of Criminal Procedure and the law stipulate that the Ministry of Justice, when it receives a criminal decision given abroad to Albanian or foreign citizens or stateless, but residing in the Albanian state, or to persons proceeded criminally in the Albanian state, sends to the prosecutor at the court of the judicial district of the place of residence or stay of the person, a copy of the decision and the relevant documentation, together with the translation into Albanian².

The Ministry of Justice, when it receives a request for recognition of a foreign criminal decision by the sentencing State in a foreign language, may request the sentencing State to translate it into Albanian. If the translation is performed by the Ministry of Justice, the translation costs are recorded to be included as part of the procedural costs ${ }^{3}$.

The Ministry of Justice has the obligation to send the acts to the prosecutor of the judicial district of the place of residence or stay of the person within 30 days from their receipt, through the General Prosecutor.

The prosecutor submits the request to the court within 10 days from the receipt of the acts. If the court that received the acts finds that it has no jurisdiction to make a decision, it declares its incompetence and sends the acts to the competent court, notifying the Ministry of Justice at the same time.

As a rule, based on the principle of solidarity between states and international obligations arising from the ratification of international conventions, states have agreed to recognize and enforce each other's court decisions, having mutual trust in the respective authorities and considering to welcome the decision of the requesting state. However, the conventions themselves provide for some exceptional cases, which are also reflected in the domestic legislation of states. Thus, Article 514 of the Criminal Procedure Code of the Republic of Albania provides certain conditions for recognition, stipulating that the decision of a foreign court cannot be recognized when:

a) the decision has not become final according to the laws of the state where it was given;

b) the decision contains dispositions contrary to the principles of the legal order of the Albanian state;

c) the decision has not been rendered by an independent and impartial tribunal or the defendant has not been summoned to appear at trial or has not been granted the right to be questioned in a language he understands and to be assisted by counsel;

d) there are reasonable grounds to believe that considerations relating to race, religion, sex, language or political beliefs have influenced the outcome of the proceedings;

e) the fact for which the decision has been given is not foreseen as a criminal offense by the Albanian law;

f) for the same fact and against the same person, in the Albanian state a final decision has been given or a criminal proceeding is conducted ${ }^{4}$.

In addition to the above conditions, Article 6 of the European Convention on the International Validity of Criminal Proceedings sets out some other conditions which may make it completely or partially impossible to recognize a foreign criminal judgment. These conditions, although not included in the content of Article 514 of the Code of

${ }^{1}$ Article 53, Law no. 10193, dated 03.12.2009 "On jurisdictional relations with foreign authorities in criminal matters", as amended.

${ }^{2}$ Article 512, The Code of the Criminal Procedure.

${ }^{3}$ Article 53, Law no. 10193, dated 03.12.2009 "On jurisdictional relations with foreign authorities in criminal matters", as amended.

${ }^{4}$ Article 514, The Code of the Criminal Procedure. 
Criminal Procedure, are reflected in the entirety of the provisions of the chapter on jurisdictional relations with foreign authorities.

Also, in view of Article 122 of the Constitution, which provides that any international agreement ratified by the Republic of Albania is part of its domestic legal system, it is worth noting that the other conditions provided by this Convention after its ratification, become mandatory for implementation and must be taken into account when applying in practice by the competent Albanian authorities.

Thus, the conditions provided by the Convention and binding for implementation are those related to the fact that the requested execution cannot be refused in whole or in part, except when:

a) the execution would be contrary to the fundamental principles of the legal order of the requested State;

b) the requested State considers the criminal offense for which the sentence has been given of a political or entirely military character;

c) the requested State considers that there is good reason to believe that the sentence was provoked or aggravated on grounds of race, religion, nationality or political belief;

d) the execution is contrary to the international commitments of the requested State;

e) the offense is the subject of proceedings in the requested State or when the latter decides to initiate proceedings in connection with this offense;

f) the competent authorities of the requested State decide not to proceed or to close the proceedings for this offense;

g) the offense was committed outside the territory of the requested State;

h) the requested State is unable to execute the sanction;

i) the request is based on Article 5 letter "a" and none of the other conditions provided in that provision has been met;

j) the requested State considers that the requesting State is itself capable of enforcing the sanction;

k) the age of the convicted person at the time of the commission of the criminal offense was such that he could not be prosecuted in the requested State;

1) the sanction is already provided for under the legislation of the requested State;

m) the decision determines the revocation or restriction of one or more rights ${ }^{5}$.

In addition to the conditions provided in Article 514 of the Code of Criminal Procedure, the foreign criminal decision is recognized and executed even when the following conditions are met:

a) if at the time of submitting the application for recognition to the Ministry of Justice, the convicted person has at least six months of imprisonment left to suffer;

b) if the execution of the sentence decision, based on domestic legislation, is not prescribed ${ }^{6}$.

Regarding the procedure followed for the implementation of a request for the recognition and execution of a foreign criminal decision, it follows the same path as other forms of international cooperation. Thus, the request of the foreign state must be submitted to the Ministry of Justice, which sends the request, together with a copy of the decision and the accompanying documentation, to the prosecutor at the court of the judicial district of the person's place of residence or stay.

The request of the sentencing state must be accompanied by the following documentation

a) the original or a single copy of the criminal decision with the determination that it is final;

5 Article 6, of the European Convention "On the international validity of criminal trials", The Hague, 28.05.1970, ratified in Albania by law no. 9068, dated 15.05.2003.

${ }^{6}$ Article 54, Law no. 10193, dated 03.12.2009 "On jurisdictional relations with foreign authorities in criminal matters", as amended. 
b) the generalities of the convicted person, including data on citizenship, place of residence and stay, place of birth, as well as other data that may be relevant for the determination of the competent court that will decide on the request;

c) data on the execution of the given decision, including information on the time spent in detention and / or serving a prison sentence;

d) a copy of the legal provisions on which the requested decision is based;

e) a summary of the progress of the criminal proceedings.

The Ministry of Justice, in case it ascertains that the request does not contain the documentation defined above, has the right to submit to the sentencing state the request for completion of the documentation, without forwarding the acts to the local judicial authorities.

Both the Ministry of Justice and the local judicial authorities, in cases where they deem it necessary during the review of the request, may request additional information from the foreign authority.

If the sentencing State fails to submit the required documents within three months, the request and the acts shall be returned to the sentencing State. However, the procedure is resumed in case of re-submission of the request and completed acts by the sentencing state ${ }^{7}$.

Regarding the manner of proceeding by the court and the deadlines that apply, Albanian law has determined that the judge of the case sets the date of the court session within 10 days from the filing of the prosecutor's request, and orders the notification of the parties in the process. The court takes into account the facts found in the foreign decision, when making the decision on the request. When recognizing a foreign decision, the court determines the sentence to be served in the Albanian state, converting the sentence determined in the foreign decision into one of the sentences provided for the same fact by the Albanian criminal legislation.

When the decision has become final, the General Prosecutor forwards to the Ministry of Justice, within 15 days from its final decision, a copy of the court decision for the recognition of the foreign criminal decision, while the Ministry of Justice, within 10 days from taking the decision of recognition by the General Prosecutor, notifies the sentencing state.

Not only the legal provisions, but also the case law has already shown that it is clear that the Albanian court when recognizing the decision of the foreign court, does not review the merits of the case and does not verify the evidence administered in the process by the foreign court. It verifies only if there are any of the conditions that prevent the recognition of the foreign decision and further, converts the sentence determined in the foreign decision with one of the penalties provided for the same fact by the Albanian criminal legislation.

The requirements that must be respected by the court when recognizing a foreign criminal decision are provided in Article 516 of the Code of Criminal Procedure, which are:

- This punishment must be responsive in nature to the one given in the foreign decision.

- The sentence can not exceed the maximum limit provided for the same fact by Albanian law.

- When the foreign decision does not specify the measure of punishment, the court imposes it on the basis of the criteria set out in the Criminal Code.

- When the execution of the sentence given in the foreign state is suspended on condition, the court has in the decision of recognition, among others, the conditional suspension of the sentence. The court does the same when the defendant is released on parole in a foreign country.

- To impose a fine, the amount imposed on the foreign decision is converted into an amount equal to Albanian Lek, applying the exchange rate of the day in which the recognition is established.

${ }^{7}$ Article 55, Law no. 10193, dated 03.12.2009 "On jurisdictional relations with foreign authorities in criminal matters", as amended. 
- In the decision of recognition for the execution of a confiscation, the execution of the confiscation is also ordered ${ }^{8}$.

Judicial practice had a period when it provided numerous examples of misunderstanding and misapplication of the above provisions. Courts of fact have often recognized and converted foreign court decisions, not only by erroneously applying the provisions on how to convert a sentence, but often by getting to the heart of the matter and undertaking to re-evaluate the facts. On the other hand, a wrong practice was followed in relation to the right to appeal against the decision of recognition and conversion of the foreign criminal decision, denying the parties the constitutional right to appeal against this decision.

These situations were regulated by the intervention of the Joint Colleges of the Supreme Court, which in the unifying decision no. 154, dated 15.04.2000, with the object "Termination of the punishment for the criminal offense of production and sale of narcotics and illegal border crossing", has ascertained that:

"............ Holding the above position, the United Colleges reach the conclusion that Law no. 8202, dated 27.03.1997 "On amnesty", does not extend its effects to Albanian citizens who have committed criminal offenses outside the Albanian territory and for which they have been convicted with a final decision by the foreign judicial authority at the time of its entry into force, neither directly, nor after their transfer to Albania.

According to this Law, are excluded from criminal prosecution and further serving of punishment all persons who have committed criminal offenses for which that law states. Law no. 8268, dated 22.12.1997 amended the time extension of the above law until 30.1.1998 for those persons who voluntarily appeared before the competent authorities. According to the above reasoning, the Panels consider that the Law on Amnesty of 1997 does not extend its effects to the applicant both during his stay in the territory of the Greek state, and when he was transferred to the execution of the decision of that authority to continue the execution of the foreign sentence in Albania. Since Law no. 8202 dated 27.03.1997 "On amnesty", does not extend the effects to persons transferred to serve the sentence given by a foreign judicial authority in the Albanian state, the request of the convict A.H. should not be accepted and for this reason, the decision of the court of first instance is vulnerable...... $" 9$.

Also, in the unifying decision of the United Colleges of the Supreme Court, no. 5, dated 10.10.2002, with the object "Recognition of the criminal decision of the Court of Appeal of Thessaloniki (Greece) no. 651, dated 21.09.1999, in charge of the Albanian citizen L. D. ", among others it is emphasized that:

"......Both the prosecutor and the defense counsel of the convict for whom the conversion of the foreign sentence is converted, can not be denied the right to appeal against the court decision on this issue, although this type of trial is not a basic trial but a special trial (sui generis)......

..........The transfer of the convict to serve in his country the sentence given by a foreign court does not constitute a relief in terms of reducing the sentence, but a relief for the effects of his faster rehabilitation in accordance with the conditions the most favorable that the Albanian legal order can offer in this regard, but in any case, without allowing in any case the aggravation of his position in comparison with the position held in the decision of the foreign court.........."

These conclusions of the Joint Colleges of the Supreme Court are reflected in the provisions of the new law "On Jurisdictional Relations with Foreign Authorities in Criminal Matters", as amended, already explicitly sanctioning them.

If a foreign criminal decision has also been expressed for the civil obligation, the interested person has the right to ask the Albanian court, with the validation decision to oblige the civil convict against him. The Albanian court in this case has limited jurisdiction and the interested person cannot file a separate lawsuit regarding his request to a civil court. His only option is provided by Article 513 of the Code of Criminal Procedure, according to which:

\footnotetext{
${ }^{8}$ Article 516, The Code of the Criminal Procedure.

${ }^{9}$ Unifying decision of the United Colleges of the Supreme Court no. 154, dated 15.04.2000.

${ }^{10}$ Unifying decision of the United Colleges of the Supreme Court no. 5, dated 10.10.2002.
} 
i. At the request of the interested party, in the same proceeding and with the same decision, the civil dispositions of the foreign criminal decision regarding the obligation for the return of the property or the compensation of the damage can be declared valid.

ii. In other cases the request is made, by the one who has an interest, in the court where the civil dispositions of the foreign criminal decision would be executed.

Regarding the possibility of imposing security measures at the gate procedure for the application of this form of cooperation, given the fact that one of the main purposes of this form is to prevent the person from escaping punishment, our criminal legislation has provided the possibility that in cases when there are conditions and criteria for its implementation, to take a coercive measure against the person or even a property security measure.

The court then has the obligation that within 5 days from the execution of the measure, take measures to identify the person and notify him of the right to have a defense counsel. The coercive measure is revoked when 3 months have passed from the beginning of its execution, without being given the decision of recognition by the district court or six months without taking the final decision.

Regarding the execution of the Albanian court decision that recognizes a foreign criminal decision, the decisions with imprisonment are executed by the prosecutor at the court that gave the decision, calculating for the effects of the execution also the time of the sentence served in the requesting state. While the amounts derived from the execution of fined decisions are deposited in the Bank of Albania and the confiscated items are transferred in favor of the Albanian state, except in cases when we are in conditions of reciprocity, when the obtained values are transferred in favor of the requesting state.

\section{Execution abroad of Albanian criminal decisions.}

The right to request the recognition and execution of a court decision also applies to the Albanian state in cases where the Albanian court has given a sentence to a person who has committed a criminal offense, but who is not in Albania. In these cases, the Ministry of Justice may address the state where the person has his residence or domicile, with a request for recognition and execution of the Albanian criminal decision. Such a request can be made in cases when the sentencing decision in Albania was given in absentia, when the requested state has rejected the request for extradition of the person, when extradition is impossible in full, or in cases where there is an international agreement. As a rule, the execution abroad of an Albanian court decision is required for foreign nationals residing or residing in another state, but it can also be required for Albanian citizens or stateless persons who have their domicile or residence in one foreign state.

As mentioned above, another case of the request for recognition and execution of the foreign court decision, is also the one initiated at the request of the convicted person himself, who is serving the sentence in the place where the sentence was given. The convict has the right to request that the remaining part of the sentence be served in his country of origin. The conditions and procedures for this request according to the Albanian legislation are provided in the provisions of the Code of Criminal Procedure.

To the conditions provided in Article 519 of the Code of Criminal Procedure, the law "On jurisdictional relations with foreign authorities in criminal matters", as amended, has added two other requirements.

Thus, the Ministry of Justice requests the recognition and execution of criminal decisions by a foreign state even when:

a) the criminal decision given by a local judicial authority cannot be executed within the Albanian territory; or

b) the execution of the criminal sentence abroad can serve a better social rehabilitation of the convicted person. 
In submitting this request, the Ministry of Justice is based on the information and documents provided by the General Prosecutor ${ }^{11}$.

The Code of Criminal Procedure provides two conditions for requesting the execution abroad of a criminal sentence handed down by an Albanian court:

i. the necessary consent of the convict, which must be given before the Albanian court and if he is abroad, the consent can be given before the Albanian consular authority or before the court of the foreign state (Article 520);

ii. prohibition of the Ministry of Justice to request the execution abroad of a criminal decision punishing a restriction of personal liberty when there is reason to consider that the convict will be subjected to persecuting or discriminatory acts due to race, religion, sex, nationality, language or beliefs or punishments and cruel, inhuman or degrading treatment (Article 521).

At the moment when the sentence decision of the Albanian court begins to be executed in the foreign state, the execution in Albania is suspended and it cannot be re-executed if the sentence is fully paid according to the law of the foreign state. It is important to note in this regard that, while serving the sentence, the person may benefit from the amnesty or pardon granted under the legislation of the state where he is serving the sentence. In this regard, the law provides that, in case the sentence is reduced, pardoned or amnestied by the sentencing state, the Minister of Justice, based on the principle of reciprocity with the sentencing state, forwards the acts sent by the sentencing state to the execution prosecutor, through the General Prosecutor. The execution prosecutor submits a request to the court that issued the recognition decision, which declares with a decision, as the case may be, the reduction or termination of the sentence.

\section{Criminal judicial cooperation in the European Union. Mutual recognition of court decisions.}

The functioning of the European Union is regulated by a treaty signed by all the member states of the European Union, which very clearly defines the competencies that the member states have given to the European institutions.

The Maastricht Treaty provided for the revision of the treaties, in order to ensure a better efficiency of the community institutions in the context of the forthcoming EU enlargement. It was followed by a difficult period for European integration, a period which, however, was overcome little by little and with sacrifices. When the provisions of the Maastricht Treaty were finally accepted, work began on the creation of a new treaty, which would mark a new step forward on the path to integration.

Thus, in Amsterdam, on 16-17 June 1997, the heads of state and government of the 15 countries of the European Union reached a political agreement on a new treaty for Europe, the Treaty of Amsterdam.

The Amsterdam Treaty of 1997 stipulates that the EU must maintain and develop an area of freedom, security and justice within the European Union.

In the framework of intergovernmental cooperation, the countries will strengthen their actions in the fight against terrorism, organized crime, pedophilia, drug and arms trafficking, fraud and corruption.

The realization of these aspirations requires as a necessary premise, a common judicial space, in which European citizens can address the judiciary of a member state in the same way as they address the state of which they are citizens. On the other hand, the possibility for perpetrators of criminal offenses to benefit from the chaos created as a result of changes between the legal systems of the member states should be eliminated or minimized as much as possible. Therefore, a mutual recognition of judicial decisions, recognized and enforceable even outside the borders of a member state, was urgent, without the need to implement the classical conventions governing international cooperation in the criminal field.

\footnotetext{
${ }^{11}$ Article 62, Law no. 10193, dated 03.12.2009 "On jurisdictional relations with foreign authorities in criminal matters", as amended.
} 
In the framework of the Tampere European Council 1999, the participants concluded that mutual recognition of judicial decisions is the cornerstone of judicial cooperation between EU member states. Judicial cooperation in the criminal field within the EU is based on several Community instruments adopted under Title VI of the Treaty on European Union, which is increasingly based on the principle of mutual recognition ${ }^{12}$.

The legislative technique used to pass the provisions governing the criminal field has undergone a real evolution. Conventions were initially preferred, while framework decisions and Council decisions regulate the area of judicial co-operation within the EU.

It is easily understood that the purpose of this transformation has been and remains the simplified procedure for the implementation of such decisions in relation to that of a convention, which in order to be implemented, must be ratified by the member states. On the other hand, the time required for the entry into force of a framework decision is much shorter than that required for the entry into force of a convention.

In this context, the most important development in European legislation can be considered the adoption of framework decision no. 584, dated 13.06.2002, which regulates the European Prohibition Order (EPO). As a result of this Framework Decision, extradition procedures applied up to that point between Member States are no longer applicable. The extradition procedure (surrender according to EPO) is now a more flexible procedure, similar to the arrest procedure used by local authorities.

The framework decision on the European Prohibition Order is seen as a more efficient instrument in relation to extradition, which requires a longer time and a stricter procedure. It represents the first concrete instrument in the criminal field, which applies the principle of mutual recognition. The EPO is issued in the form of a judicial decision by a judicial authority of a Member State, with the aim of detaining or extraditing from other Member States persons wanted for the purpose of prosecuting or punishing them. The decision of a judicial authority of a Member State regarding the detention and return of a person should be executed as quickly and easily as possible in other EU Member States.

National courts may issue an EPO to detain or extradite a person wanted by a Member State, with a view to:

(i) the conduct of a criminal proceeding;

(ii) the execution of a decision on a measure of imprisonment;

(iii) the execution of a restraining order.

The State to which the EPO is addressed does not have the right to discuss the reasons or causes on which the extraction of the EPO is based, due to the principle of mutual trust between the judicial systems of the member states. This makes the execution of EPOs very fast.

The Framework Decision for the EPO brought some innovations in relation to previous extradition procedures within the Council of Europe:

1. Simple procedure: without formalities and excessive bureaucracy. The application of the principle of double punishment for the category of 32 serious violations has been avoided, which includes offenses such as: participation in a criminal organization, terrorism, trafficking in human beings, sexual exploitation of children and child pornography, illegal trafficking in weapons, ammunition and explosives, corruption, fraud including fraud related to EU financial interests, money laundering and counterfeiting of money including the international currency Euro.

2. Accelerated procedure: The state in which the person is detained must deliver it to the state in which the detention order was issued, within a maximum period of 90 days from the detention. If the person consents to the delivery, the decision must be made within 10 days.

${ }^{12}$ http://data.europa.eu/eli/dec_framw/2002/584/oj

2002/584/JHA: Council Framework Decision of 13 June 2002 on the European arrest warrant and the surrender procedures between Member States - Statements made by certain Member States on the adoption of the Framework Decision. 
3. Depoliticization of procedures: The part of "political decision-making" has been avoided, making the execution of an EPO a mere judicial process.

4. Extradition of its nationals: Under the 1957 Extradition Convention, the extraditing State may refuse the extradition of its national. Meanwhile, member states cannot refuse the surrender of their citizens. The surrendering state during the surrender procedure, may request that its citizen, after being tried, return to his country to serve the sentence, in order for the rehabilitation function to be achieved more quickly.

It is important to note that, both during the extradition procedure and during the execution of an EPO, states and national courts must ensure that the provisions of the ECHR are complied with. The framework decision reflected the jurisprudence of the ECHR regarding trial in absentia, bypassing the legal provisions of the countries. It stipulates that if the individual has been tried and subsequently detained on the basis of an EPO, he has the right to be extradited to the requesting country, to undergo a trial, in his presence.

\section{Albanian legal framework in the integration process.}

As it is already known, one of the main tasks of Albania in its EU integration process is the approximation of its legislation with the acquis communautaire. In the field of criminal judicial cooperation, as we have mentioned above, one of the most important laws adopted by the Republic of Albania is the one with no. 10193, date. 03.12.2009 "On jurisdictional relations with foreign authorities in criminal matters", which has undergone some changes in 2013.

The provisions of this law will apply:

a) in proceedings related to criminal offenses, which at the time of filing the request, are under the jurisdiction of the judicial authorities of the requesting state or in the Republic of Albania;

b) in proceedings that are under the jurisdiction of the European Court of Human Rights or other international courts, whose jurisdiction has been accepted by the Republic of Albania.

The above law has been able to regulate all forms of judicial cooperation in the criminal field and the procedures followed by the relevant authorities in their implementation. 
ISSN 2661-2666 (Online) International Scientific Journal Monte (ISJM) DOI: 10.33807/monte.20211893

Volume 4, (No).2 (2021): April

\section{REFERENCES}

1. Law no. 10193, dated 03.12.2009 "On jurisdictional relations with foreign authorities in criminal matters", as amended.

2. The Code of the Criminal Procedure.

3. European Convention "On the international validity of criminal trials", The Hague, 28.05.1970, ratified in Albania by law no. 9068, dated 15.05.2003.

4. Unifying decision of the United Colleges of the Supreme Court no. 154, dated 15.04.2000.

5. Unifying decision of the United Colleges of the Supreme Court no. 5, dated 10.10.2002.

6. http://data.europa.eu/eli/dec_framw/2002/584/oj

2002/584/JHA: Council Framework Decision of 13 June 2002 on the European arrest warrant and the surrender procedures between Member States - Statements made by certain Member States on the adoption of the Framework Decision. 